\title{
/PEPTIDE PRODUCTS
}

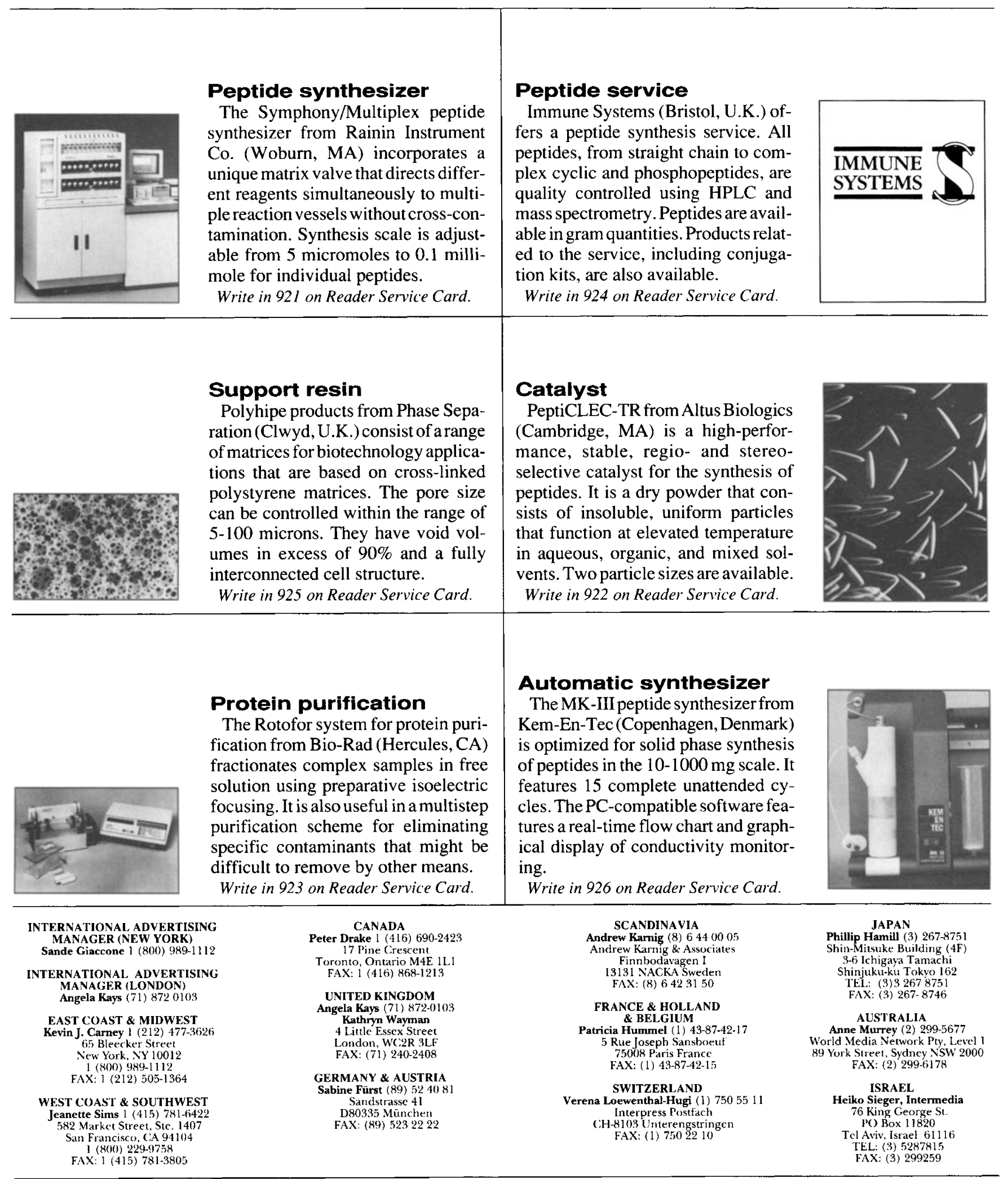

